\title{
Eksistensi Stabilization Clause Dalam Kontrak Karya Sehubungan Dengan Berlakunya Undang-Undang Nomor 4 Tahun 2009
}

\author{
Pamungkas Hudawanto \\ Magister Kenotariatan Fakultas Hukum Universitas Islam Indonesia Yogyakarta Indonesia \\ Jln. Cik Di Tiro No. 1 Yogyakarta Indonesia \\ pamungkas.hudawanto@gmail.com
}

\begin{tabular}{ll}
\hline Key Word: & Abstract \\
Agreement, PT. & There are several foreign companies engaged in the management of Mineral and \\
Newmoont, stability & Coal in Indonesia such as PT. Newmoont. In its development, the Indonesian \\
clause & government stated that the working relationship between the government and the \\
company needed to be changed from a Contract of Work system to a Special Mining \\
Business Permit. However, the permissibility of this change is questioned by the \\
existence of a stabilization clause principle. The formulation of the problem in this \\
study is how the existence and use of the stabilization clause in the contract of work \\
relates to the enactment of Law Number 4 of 2009. This research is a normative \\
research using 2 (two) approaches, namely the statutory and the conceptual \\
approaches. The results of this study conclude that the stabilization clause still \\
exists in Law Number 4 of 2009 and is useful for ensuring the operational activities \\
of PT. Newmoont Indonesia according to the Contract of Work that has been made \\
until the expiration of the contract/agreement
\end{tabular}

\section{Kata-kata Kunci: $\quad$ Abstrak}

Perjanjian, klausa Terdapat beberapa perusahaan asing yang bergerak dalam engelolaan stabilitas, PT Minerba di Indonesia seperti PT. Newmoont. Dalam perkembangannya Newmooont pemerintah Indonesia menyatakan bahwa hubungan kerja antara pemerintah dengan perusahaan tersebut perlu diubah dari sistem Kontrak Karya menjadi Ijin Usaha Pertembangan Khusus. Namun, kebolehan atas perubahan ini dipertanyakan dengan adanya asas tabilization clause. Rumusan masalah dalam penelitian ini yakni bagaimanakah eksistensi dan kegunaan stabilization clause dalam kontrak karya sehubungan dengan berlakunya Undang-Undang Nomor 4 Tahun 2009. Penelitian ini merupakan penelitian normatif dengan menggunakan 2 (dua) pendekatan yakni pendekatan perundang-undangan dan pendekatan konseptual. Hasil dari penelitian ini yakni stabilization clause tetap eksis dalam UndangUndang Nomor 4 Tahun 2009 dan berguna untuk menjamin kegiatan operasional PT. Newmoont Indonesia sesuai Kontrak Karya yang telah dibuat sampai jangka waktu berakhirnya kontrak/perjanjian.

\section{Pendahuluan}

Salah satu tujuan utama dari keberadaan Negara Kesatuan Republik Indonesia adalah meningkatkan kesejahteraan masyarakat. Oleh karena itu, untuk mencapai tujuan tersebut, maka segala sumber daya yang ada di Indonesia harus diupayakan, mengingat Indonesia adalah negara yang begitu kaya akan sumber daya alam dan energinya. Sumber daya alam yang dimaksud adalah segala macam kekayaan yang terkandung di dalam bumi yang dapat digunakan untuk kesejahteraan masyarakat Indonesia. Sumber daya alam digolongkan dua macam, yaitu sumber daya alam yang dapat diperbarui dan yang tidak dapat diperbarui. Sumber daya alam yang tidak dapat diperbarui salah satu 
contohnya adalah bahan galian(tambang), bahan galian yang dimaksud antara lain meliputi minyak dan gas bumi (migas), batubara, emas, perak, dan tembaga.

Amanat untuk pengelolaan sumber daya alam ini tertuang dalam konstitusi UUD 1945 Pasal 33 yang berbunyi bumi, air dan kekayaan alam yang terkandung didalamnya dikuasai oleh negara dan dipergunakan sebesar-besarnya untuk kepentingan rakyat. Dengan masuknya modal asing, kemudian tujuan-tujuan lain yang ingin dicapai dapat terlaksana seperti mengembangkan industri subtitusi impor untuk menghemat devisa, mendorong ekspor non-migas untuk menghasilkan devisa, alih teknologi, membangun prasarana dan perkembangan daerah tertinggal. ${ }^{1}$

Berdasarkan ketentuan ini, maka pada prinsipnya negara diberi tugas untuk mengatur dan mengusakan sumber daya alam yang wajib ditaati oleh seluruh rakyat Indonesia, juga sumber daya alam untuk kemakmuran rakyat. Apbila hal ini merupakan kewajiban negara, maka pada sisi lai merupakan hak rakyat Indonesia untuk mendapatkan kemakmuran melalui pemanfaatan sumber daya alam. Kewajiban ini merupakan amanat konstitusi, dan sebagai perwujudan tanggung jawab sosial dari negara sebagai konsekuensi dari hak penguasaan tersebut.

Pada awal dimulainya pembangunan, pembiayaan sebagian besar berasal dari eksploitasi sumber daya alam migas, sumber daya hutan dan pinjaman luar negeri. Kebutuhan akan modal untuk melaksanakan program-program pembangunan tentunya tidak akan dapat dibiayai dengan hanya menggunakan anggaran belanja dalam negeri, terlebih bantuan luar negeri akan sulit diperoleh. Pinjaman luar negeri yang bersifat komersial memang tersedia, akan tetapi tentunya harus digunakan secara hati-hati karena merupakan beban terhadap neraca pembayaran. ${ }^{2}$ Dilihat dari sejarah munculnya pola Kontrak Karya di Indonesia, banyak pihak berpendapat bahwa kedudukan para pihak dalam Kontrak Karya tidak seimbang, dengan posisi Pemerintah Indoensia yang lebih lemah dalam merundingkan kerangka investasi asing di Industri Pertambangan ${ }^{3}$.

Untuk berusaha di bidang pertambangan, investor asing memerlukan jaminan hak untuk menambang (right to mine) sebelum melakukan penelitian dan eksplorasi untuk menemukan mineral, untuk itulah investor menghendaki bahwa semua persyaratan tentang hak da kewajiban sudah disepakati (nailed down) sejak sebelum adanya kegiatan. Konsekuensi dari keadaan ini dari pemerintah adalah bahwa pemerinta tidak dapat berbuat lain kecuali menerima saja apapun hasil eksplorasi. ${ }^{4}$

Pemerintah Indonesia juga tidak memperoleh keuntungan (gain) yang berarti dari hasil penambangan yang dilakukan. Di Indonesia terdapat beberapa perusahaan asing yang bergerak di sektor minerba diantaranya yang paling besar adalah adalah PT. Newmoont Indonesia, PT Newmoon, PT. Antam, PT. Adaro Energi Tbk, PT. Vale Indonesia, PT. Pertamina, PT. Chevron Indonesia, dll. Sebagai salah satu contoh PT. Newmoont Indonesia yaitu perusahaan yang bergerak dibagian pertambangan yang

${ }^{1}$ H. Salim HS., dan Budi Sustrisno, Hukum Investasi di Indonesia,PT Rajagrafindo Persada, 2008, hlm. 354

2 Nanik Tri Hastuti, Hukum Kontrak Karya, Setara Press 2013, hlm. 5

${ }^{3}$ Ibid., hlm. 6.

${ }^{4}$ Geoarge A. Maley, sebagaimana dikutip dari Arianto Sangaji, Buruk Inco Rakyat Digusur, Pustaka Sinar Harapan, Jakarta, 2002, hlm. 76 
sebagian besar sahamnya dimiliki oleh Newmoont, barang tambang yang dihasilkan adalah tembaga, emas, perak , dan lain-lain. ${ }^{5}$

PP Nomor 23 Tahun 2010 menyatakan bahwa perpanjangan Kontrak Karya dapat dilakukan dua tahun sebelum masa kontraknya selesai. Beberapa waktu yang lalu, Kementerian ESDM menyampaikan usulan kepada PT Newmoont Indonesia, agar hubungan kerja antara Pemerintah Indonesia dengan Newmoont diubah dari sistem kontrak karya menjadi Ijin Usaha Pertambangan Khusus.

\section{Rumusan Masalah}

Bagaimanakah eksistensi dan kegunaan Stabilization Clause dalam Kontrak Karya sehubungan dengan berlakunya Undang-Undang Nomor 4 Tahun 2009?

\section{Tujuan Penelitian}

Penelitian ini bertujuan untuk mengkaji kegunaan stabilization clause dalam perkembangan Kontrak Karya yang ada di Indonesia.

\section{Metode Penelitian}

Penelitian ini merupakan penelitian normatif dengan metode deskriptif. Pendekatan yang digunakan penulis adalah pendekatan peraturan perundang-undangan dan pendekatan konseptual. Bahan hukum yang digunakan meliputi bahan hukum primer, sekunder dan tersier. Adapun dalam pengumpulan data, penulis menggunakan studi pustaka yaitu mengumpulkan, membaca serta mengkaji peraturan perundangundangan, buku-buku, literatur-literatur, jurnal, makalah, surat kabar, dan dari internet yang berhubungan dengan permasalahan penelitian.

\section{Hasil Penelitian dan Pembahasan}

\section{Eksistensi dan Kegunaan Stabilization Clause dalam Kontrak Karya Pasca dengan Berlakunya Undang-Undang Nomor 4 Tahun 2009}

Salah satu tujuan pengelolaan mineral dan batubara adalah untuk men-dukung dan menumbuhkembangkan kemampuan nasional agar lebih mampu bersaing di tingkat nasional, regional, dan internasional, ${ }^{6}$ oleh sebab itu mineral dan batubara sebagai sumber daya alam yang tak terbarukan merupakan kekayaan nasional yang dikuasai oleh negara untuk sebesar-besar kesejahteraan rakyat, harus diselenggarakan oleh pemerintah dan/atau pemerintah daerah. ${ }^{7}$ Meski demikian, faktanya sebagian besar kekayaan alam Indonesia justru tidak kelola oleh pemerintah dan/atau pemerintah daerah, melainkan oleh orang asing. Seperti halnya yang terjadi di tambang emas di Kabupaten Mimika, Papua, yang saat ini dikelola oleh PT. Newmoont Indonesia melalui Kontrak Karya.

5http:// Newmoont.com. Diakses pada 16 Januari 2017 pukul 21.15 wib

${ }^{6}$ Pasal 3 Undang-Undang Nomor 4 Tahun 2009 tentang Pertambangan Mineral dan Batubara.

${ }^{7}$ Pasal 4 ayat (1) dan ayat (2) Undang-Undang Nomor 4 Tahun 2009 tentang Pertambangan Mineral dan Batubara. 
Kontrak Karya penambangan emas di Kabupaten Mimika, Papua, yang ditandatangani oleh pemerintah Indonesia dengan PT. Newmoont Indonesia tahun 1967, didasarkan pada Undang-Undang Nomor 1 Tahun 1967 tentang Penanaman Modal Asing dan Undang-undang Nomor 11 Tahun 1967 tentang Ketentuan-Ketentuan Pokok Pertambangan. Hal ini berarti bahwa pemerintah berkedudukan sebagai salah satu pihak (badan hukum publik) dalam Kontrak Karya tersebut, dan PT. Newmoont Indonesia sebagai pihak (badan hukum privat) lainnya.

Pada penambangan pertamanya dengan luas eksploitasi 10 hektare yang dilakukan pada 1973, PT. Newmoont Indonesia dibebaskan dari kewajiban membayar pajak selama tiga tahun pertama. Tiga tahun berikutnya, PT. Newmoont Indonesia dikenakan konsesi pajak 35 persen. Setelahnya, baru meningkat menjadi 41,75 persen. Royalti yang wajib diberikan kepada pemerintah adalah 1,5-3,5 persen untuk tembaga dan 1 persen untuk emas serta perak. Jika Kontrak Karya dimulai pada 1967 sehingga berlaku 30 tahun, maka seharusnya Kontrak Karya I berakhir pada 1997. Dan akhirnya pada 1991 (6 tahun sebelum kontrak habis), pemerintah menerbitkan Kontrak Karya II dengan berbagai catatan untuk mereka. ${ }^{8}$

Pada 12 Juli 2018, pemerintah Indonesia menandatangani Head of Agreement (HoA) dengan pihak FCX di Kementerian Keuangan. Indonesia diwakili oleh Direktur Utama PT. Indonesia Asahan Aluminium (Inalum) Budi Gunadi Sadikin, sementara FCX diwakili oleh Richard Adkerson selaku Presiden Direktur. Penandatangan Kontrak Karya II dilakukan oleh Menteri Pertambangan dan Energi Indonesia, Ginandjar Kartasasmita dan pihak FCX. Berdasarkan kontrak tersebut, PT. Newmoont Indonesia bisa beroperasi hingga 30 tahun kemudian yaitu sampai 2021. Tidak hanya itu, PT. Newmoont Indonesia juga berhak mengajukan perpanjangan dua kali 10 tahun hingga 2041. Lahan yang dikuasai PT. Newmoont Indonesia juga bertambah luas dari hanya 10 ribu hektare menjadi 2,6 juta hektare atau sekitar 6,2 persen wilayah Papua (termasuk di dalamnya adalah tanah adat) .9

Dalam keberjalanannya, PT. Newmoont Indonesia kerap menimbulkan kontroversi mengenai aktivitas pertambangan mereka. Seperti halnya tentang divestasi saham yang harusnya diberikan kepada pemerintah Indonesia sebesar 10 persen pada 10 tahun pertamanya sejak perpanjangan pada 1991 yaitu pada 2001. Kemudian bertambah pada 10 tahun berikutnya, pada 2011, PT. Newmoont Indonesia seharusnya juga harus memerikan divestasi saham sebesar 50 persen. Tetapi pada tahun 2011 PT. Newmoont Indonesia tidak melaksanakan prestasinya tersebut, barulah pada tahun 2018, divestasi 10 persen baru diberikan untuk pemerintah Indonesia.

Selain mengenai pemenuhan saham, permasalahan lain yang terjadi dalam investasi pertambangan oleh PT. Newmoont Indonesia adalah tentang pelanggaran lingkungan dan Hak Asasi Manusia (HAM). PT. Newmoont Indonesia diketahui telah melakukan pelanggaran hukum dengan merusak lingkungan di sekitar tambang. Kementerian Lingkungan Hidup dan Kehutanan telah menemukan setidaknya 47

\footnotetext{
Rosa Folia, Memahami Sejarah Panjang Kontrak Newmoont di Indonesia, https://www.idntimes.com/business/economy/rosa-folia/memahami-sejarah-panjang-kontrak-Newmoont-diindonesia $/ 5$, Akses 18 Oktober 2020.

${ }^{9}$ Ibid.
} 
pelanggaran. Ekosistem mulai dari sungai, kawasan hutan mangrove, hingga lautan pun terkena dampak akibat limbah pertambangan. ${ }^{10}$

Pencemaran ini berasal dari kolam penampungan limbah pasir sisa tambang atau yang sering dikenal dengan istilah Modified Ajkwa Deposition Area (ModADA). Metode ini dianggap buruk karena tidak ramah lingkungan. Kementerian Lingkungan Hidup dan Kehutanan pun memberikan sanksi administratif pada PT. Newmoont Indonesia. Sanksi tersebut berupa kewajiban untuk merehabilitasi lingkungan dan memantau limbah hasil tambang. Jika tidak, kementerian mengancam pembekuan operasi sampai kerusakan lingkungan tersebut ditangani.

Selain lingkungan, pelanggaran lain yang dilakukan oleh Newmoont Indonesia adalah pelanggaran HAM. Salah satu bentuk pelanggaran HAM yang paling terkenal dilakukan oleh PT. Newmoont Indonesia adalah ketika runtuhnya terowongan Big Gossan di 2013. Kecelakaan tambang yang menewaskan 28 pekerja ini dianggap sebagai tindakan pelanggaran HAM karena PT. Newmoont Indonesia tidak memerhatikan kondisi tempat pekerjanya sebagai bagian dari hak hidup pekerja. Pelanggaran ini tentu saja perlu ditindaklanjuti dengan tegas agar ke depannya tidak ada lagi kelalaiankelalaian yang dapat merenggut nyawa pekerja.

Dari sisi investor (PT. Newmoont Indonesia), perkembangan situasi negara Indonesia yang berubah-ubah menimbulkan suatu risiko kerugian yang besar. Mengingat bahwa Kontrak Karya adalah sebuah perjanjian dalam jangka panjang, maka PT. Newmoont Indonesia bersepakat dengan pemerintah untuk menggunakan stabilization clause dalam perikatannya. Sebagaimana yang telah dijelaskan di atas, bahwa Kontrak Karya I ditandatangi pada masa Soeharto 1967, maka jangka masa habisnya Kontrak Karya pastilah melewati masa-masa perpindahan kekuasaan presiden Indonesia.

Setelah 32 tahun Soeharto menjadi presiden, dan saat terjadinya pemberontakan mahasiswa untuk menuntut turunnya Soeharto pada 1998, maka sudah dipastikan situasi negara saat itu menjadi begitu kacau. Ekonomi, politik, dan sosial begitu tidak stabil karena guncangan reformasi. Setelahnya, tampuk presiden jatuh ke tangan Habibie, yang juga pada masa ini merupakan masa pascareformasi. Di mana masa yang berat dalam transisi pemerintah dari rezim otoriter ke demokrasi seutuhnya. Habibie tidak bertahan lama, kemudian kekuasaan dilimpahkan pada Abdurrahman Wahid (Gusdur). Selanjutnya Gusdur dengan skandal Bulog-nya tidak bisa bertahan lama dalam memimpin Indonesia, meski lebih lama sedikit daripada Habibie.

Megawati Soekarno Putri akhirnya melanjutkan estafet presiden kala itu. Sampai pada akhirnya Indonesia mengenyam demokrasi yang mengimplementasikan pemilihan langsung pada 2004. Susilo Bambang Yudhoyono (SBY) keluar sebagai presiden terpilih. SBY memimpin Indonesia selama dua periode, setelah pada 2009 SBY kembali memenangkan pesta demokrasi. Tahun 2014, bergantilah presiden Indonesia yaitu Joko Widodo alias Jokowi. Keberlangsungan Jokowi sebagai presiden tak kalah maraknya dengan pendahulu. Dikotomi dua kubu antara pendukung dua calon presiden kala itu:

\footnotetext{
10 Hafizh Mulia, Sejarah Newmoont di Indonesia dan Mengapa Keberadaannya Begitu Kontroversial,https://asumsi.co/post/inilah-sejarah-dan-pelanggaran-pelanggaran-yang-dilakukan-Newmoontselama-di-indonesia, Akses 18 Oktober 2020, 01.00 WIB
} 
pendukung Jokowi dan pendukung Prabowo. Iklim politik yang sengit bahkan kerap berujung kekerasan dan pemidanaan. Tetapi dengan segala dinamikanya, Jokowi berhasil menyelesaikan satu periodenya yang habis pada 2019. Kemudian dilanjutkannya lagi, dan kembali terpilih hingga hari ini, hingga masa baktinya berakhir pada 2024 kelak.

Mengetahui serentetan sejarah pergantian presiden dan pemerintah di Indonesia sejak orde baru hingga reformasi, memberikan gambaran tentang bagaimana perubahanperubahan terus menerus terjadi, sejurus dengan pergantian presiden. Dinamika global maupun nasional seperti mustahil untuk dielakkan dan bahkan menjadi suatu keniscayaan. Kebijakan demi kebijakan lahir dari siapa yang menjadi pemimpin saat itu. Perubahan pun demikian, sejalan dengan adanya berbagai kebijakan dan situasi yang demikian kompleks.

Dalam upaya meminimalisir dampak dari berbagai dinamika negara Indonesia, jauh-jauh hari dalam kesepakatan PT. Newmoont Indonesia dengan pemerintah menerapkan stabilization clause. Dalam klausul ini, menyatakan bahwa kontrak pertambangan (concession agreements) yang ditandangani hari ini, berdasarkan hukum positif yang berlaku hari ini dan tidak boleh di rubah seenaknya oleh para pihak dalam perjanjian. ${ }^{11}$ Meski dalam stabilization clause menjamin ketidakpengaruhan isi kontrak sekalipun terjadi perubahan, namun mengingat bahwa posisi pemerintah sebagai negara yang berdaulat, maka apabila terjadi perubahan iklim politik, ekonomi, dan sebagainya, yang justru akan menimbulkan kerugian bagi masyarakat Indonesia, kontrak tetap bisa berubah dengan berprinsip pada tindakan adil dan layak (fair and equitable treatment/FET).

Prinsip kedaulatan negara bukan merupakan klaim sepihak, melainkan telah diterima dan ditegaskan dalam beberapa putusan arbitrase. Sebagai contoh, putusan Parkerings v Lithuania (2007) menegaskan, kewenangan negara untuk mengatur merupakan hak dan privilese yang tidak dapat disangkal (undeniable rights and privilege). Meski demikian, penerapan prinsip kedaulatan negara tersebut tidak serta-merta memberikan kewenangan mutlak bagi negara untuk bertindak sewenang-wenang. Pembatasan terhadap prinsip tersebut perlu dilakukan untuk memberikan kepastian dan jaminan bagi investor guna mendapatkan proyeksi keuntungan yang diharapkan dari investasi tersebut di masa depan.

Posisi hukum Internasional terkait ini adalah menyeimbangkan antara jaminan atas keuntungan yang diharapkan (legitimate and reasonable expectations) dan hak negara dalam mengatur untuk kepentingan publik, sebagaimana ditegaskan dalam beberapa putusan arbitrase (Saluka v the Czech Republic (2006) dan Suez v Argentina (2010)).

Salah satu prinsip yang berkembang untuk menyeimbangkan antara kedaulatan negara vis a vis kepastian berusaha adalah dengan mengembangkan standar FET (fair and equitable treatment). Pada prinsipnya, standar FET menegaskan beberapa prinsip yang perlu diperhatikan bagi negara untuk menerapkan kedaulatannya dalam mengatur, yang dapat berdampak pada ketentuan stabilisasi sebuah kontrak. Prinsip tersebut meliputi nondiskriminatif, jaminan atas kepastian proyeksi keuntungan, dan tidak dilakukan secara sewenang-wenang.

${ }^{11}$ Giri Ahmad Taufik, Peneleti Pusat Studi Kebijakan Hukum, Kompas, 11-7-2014. 
Prinsip tersebut membatasi tindakan Indonesia dalam memaksa PT. Newmoont Indonesia untuk menyesuaikan dengan Undang-Undang Minerba. Pertama, prinsip nondiskriminatif mensyaratkan bahwa tindakan Pemerintah tidak hanya berlaku pada PT. Newmoont Indonesia semata. Kedua, prinsip jaminan kepastian proyeksi keuntungan investasi mensyaratkan bahwa Indonesia harus menghormati proyeksi keuntungan yang ingin didapat oleh PT. Newmoont Indonesia saat investasi dilakukan. Ketiga, prinsip melaksanakan secara tak sewenang-wenang mensyaratkan bahwa tindakan pemerintah harus dengan proses yang berkeadilan dan layak.

Jika ditilik proses yang terjadi dalam lebih kurang tujuh tahun terakhir, dapat dikatakan bahwa Indonesia sebenarnya telah melaksanakan standar FET dalam melaksanakan Undang-Undang Minerba. Pada prinsip nondiskriminatif, pemberlakuan Undang-Undang Minerba tak hanya diterapkan pada subyek hukum asing semata, tetapi juga pada subyek hukum Indonesia. Pada prinsip kedua, bisa dilihat bahwa sebenarnya semua kewajiban di dalam Undang-Undang Minerba sudah tertera di dalam KK 1991 PT. Newmoont Indoensia. Sebagai contoh, kewajiban pemurnian (Pasal 10 ayat (5) KK 1991) atau kewajiban divestasi (Pasal 24 KK 1991).

Ketika penyesuaian atas Undang-Undang Minerba yang baru oleh PT. Newmoont Indonesia tidak dilaksanakan dengan segera, salah satunya disebabkan karena PT. Newmoont Indonesia 'berlindung' pada asas klausul stabilisasi, yang justru memberikan posisi yang tidak adil bagi Indonesia. Pada dasarnya, penandatanganan kontrak karya 1991, PT. Newmoont Indonesia sebenarnya sudah memiliki proyeksi keuntungan. Sehingga jika kehendak pemerintah memaksakan hal-hal sebagaimana perubahan sesuai Undang-Undang Minerba 2009, seharusnya tidak akan mengganggu proyeksi dari PT. Newmoont Indonesia atas keuntungan yang ingin didapatnya.

Penjelasan di atas, menggambarkan bagaimana sebenarnya asas stabilization clauses tidak menutup kemungkinan adanya perubahan, selama mengandung kelayakan dan keadilan. Karena pada umumnya, terdapat tiga tipe stabilization clause, yaitu:

\section{Freezing Clauses}

Dalam klausul jenis ini hukum yang berlaku dalam kontrak hanya mengacu pada hukum pada saat kontrak ditandatangani dan akan terus berlaku sampai dengan kontrak berakhir dengan kata lain semua perubahan peraturan/hukum setelah kontrak ditandatangani tidak akan berpengaruh terhadap kontrak.

2. Economic Equilibrium Clauses

Dalam economic equilibrium clauses, dimungkinkan adanya pemberlakuan hukum/peraturan baru di dalam kontrak oleh negara di mana perusahaan/penandatangan kontrak dapat negoisasi ulang kontrak dan negara memberikan hak kompensasi.

3. Hybrid Clauses

Hybrid clause merupakan kombinasi dari dua tipe sebelumnya. Investor tidak secara otomatis dikecualikan dari pemberlakuan peraturan/hukum baru, namun investor diberikan beberapa pengecualian. Intinya negara menetapkan posisi/pengecualian hal-hal atau perubahan-perubahan apa yang mengikuti hukum baru dan hal-hal apa yang tetap sesuai hukum lama. 
Sebagaimana yang tercantum pada Undang-Undang Nomor 4 Tahun 2009 Tentang Minerba, maka PT. Newmoont Indonesia harus mengubah sistem Kontrak Karya menjadi sistem Izin Usaha Pertambangan Khusus (IUPK). Pada Pasal 103, PT. Newmoont juga berkewajiban untuk melakukan pengolahan dan pemurnian hasil penambangan di dalam negeri, selambat-lambatnya lima tahun. Selain itu, poin negosiasi yang telah disepakati oleh pemerintah dan PT. Freepoot Indonesia adalah dalam hal wilayah operasi, peningkatan local content, divestasi, dan pembangunan smelter.

Meski menurut Undang-Undang Nomor 4 Tahun 2009, PT. Newmoont Indonesia akan mengalami beberapa perubahan, namun sebagaimana tipe stabilization clauses yang telah dijelaskan di atas, pemerintah tetap menjamin kepastian operasional PT. Newmoont Indonesia. Seperti yang sudah dicantumkan pada Pasal 169 Undang-Undang Nomor 4 Tahun 2009, bahwa Kontrak Karya dan perjanjian karya perusahaan pertambangan batubara yang telah ada sebelum berlakunya Undang-Undang ini tetap diberlakukan sampai jangka waktu berakhirnya kontrak/perjanjian.

Dalam Undang-Undang Nomor 3 Tahun 2020 tentang Perubahan Atas UndangUndang Nomor 4 Tahun 2009 tentang Minerba, asas stabilization clause jelas diterapkan sebagai manifestasi dari sebuah itikad baik perjanjian (karya). Dalam Undang-Undang Nomor 3 Tahun 2020 tersebut telah disisipkan pasal baru sebagai pendukung atau penyempurnaan ketentuan dari Undang-Undang Nomor 4 Tahun 2009, salah satunya yang berkenaan dengan permasalahan PT. Newmoont Indonesia adalah jaminan keberlangsungan operasionalnya.

PT. Newmoont Indonesia diberikan jaminan perpanjangan menjadi IUPK yang sebelumnya Kontrak Karya, setelah memenuhi persyaratan dengan ketentuan:

1. Kontrak/perjanjian yang belum memperoleh perpanjangan dijamin mendapatkan 2 kali perpanjangan dalam bentuk IUPK sebagai Kelanjutan Operasi Kontrak/Perjanjian masing-masing untuk jangka waktu paling lama 10 tahun sebagai kelanjutan operasi setelah berakhirnya KK atau PKP2B dengan mempertimbangkan upaya peningkatan penerimaan negara.

2. Kontrak/perjanjian yang telah memperoleh perpanjangan pertama dijamin untuk diberikan perpanjangan kedua dalam bentuk IUPK sebagai Kelanjutan Operasi Kontrak/Perjanjian untuk jangka waktu paling lama 10 tahun sebagai kelanjutan operasi setelah berakhirnya perpanjangan pertama KK atau PKP2B dengan mempertimbangkan upaya peningkatan penerimaan negara.

Berdasarkan penjelasan di atas, maka sesungguhnya Kontrak Karya PT. Newmoont Indonesia dan pemerintah telah memakai asas stabilization clause sebagai jaminan atas kepastian investasi usaha yang dilaksanakan oleh PT. Newmoont Indonesia. Meski demikian, mengingat dinamika yang terjadi dari masa ke masa, sebagai negara yan berdaulat, Indonesia berhak melakukan perubahan atas yang telah disepakati dengan PT. Newmoont Indonesia. Perubahan yang dimaksud adalah sebagai implementasi dari tugas negara yang telah diamanahkan oleh Undang-Undang Dasar Negara Republik Indonesia tahun 1945, yaitu menguasai segala sumber daya alam (SDA) agar dimamfaatkan untuk kemakmuran rakyat. Maka jika selama ini Kontrak Karya PT. Newmoont Indonesia justru berbanding terbalik dengan UUD tahun $1945 \mathrm{itu}$, sehingga membawa ketidaksejahteraan bagi masyarakat Indonesia, pemerintah wajib melakukan 
perubahan dan menyesuaikan dengan berpegang teguh pada kehendak baik, layak, sekaligus berkeadilan.

\section{Penutup}

Berdasarkan analisis yang telah penulis paparkan pada bab-bab sebelumnya, maka penulis dapat menarik beberapa kesimpulan dalam penelitian ini, yaitu:

1. Kontrak Karya, sebagaimana termaktub pada Pasal 1 huruf a Keputusan Direktur Jendral Pertambangan Umum Nomor 150.K/20.01/DDJP/1998 tentang Tatacara, Persyaratan dan Pemrosesan permohonan Kontrak Karya, adalah kontrak antara Pemerintah Republik Indonesia dengan perusahaan berbadan hukum Indonesia untuk melaksanakan usaha pertambangan bahan galian, tidak termasuk minyak bumi, gas alam, panas bumi, radio aktif dan batubara. Dasar hukum digunakan dalam sektor pertambangan telah dijelaskan dalam Pasal 8 ayat (1) Undang-Undang Nomor 1 Tahun 1967 Tentang Penanaman Modal Asing. Pada pasal tersebut menyatakan bahwa penanaman modal asing di bidang pertambangan didasarkan pada suatu kerjasama dengan pemerintah atas dasar Kontrak Karya $(\mathrm{KK})$ atau bentuk lain sesuai dengan peraturan perundang-undangan yang berlaku.

Dipandang menggunakan aspek hukum perdata, Kontrak Karya merupakan bagian dari perjanjian: "van verbintenissen die uit contract of overenkomst" yang artinya "perikatan lahir dari kontrak atau perjanjian." Karena Kontrak Karena adalah sebuah perjanjian, maka sudah tentu ada kewajiban memenuhi sesuai apa yang dijanjikan. Sebagaimana juga yang diperintahkan oleh Allah dalam Surat Al-Ma'idah ayat 1: Hai orang-orang yang beriman, penuhilah aqad-aqad itu. Dihalalkan bagimu binatang ternak, kecuali yang akan dibacakan kepadamu. (Yang demikian itu) dengan tidak menghalalkan berburu ketika kamu sedang mengerjakan haji. Sesungguhnya Allah menetapkan hukumhukum menurut yang dikehendaki-Nya.)"

Kontrak Karya sebagai perikatan, maka mengandung asas pacta sunt servanda yang dianggap sebagai asas fundamental karena asa tersebut melandasi lahirnya suatu perjanjian. Asas pacta sunt servanda berasal dari bahasa latin yang berarti 'janji harus ditepati' (agreements must be kept), sehingga dalam hukum positif rumusan normanya menjadi: setiap perjanjian yang dibuat secara sah berlaku sebagai undang-undang bagi mereka yang dibuatnya. Selain asas pacta sunt servanda, ada juga asas rebus sic stantibus yang terdapat pada pasal 27 VCLT, "A party may not invoke the provisions of its internal law as justification for its failure to perform a treaty. This rule is without prejudice to article 46." Dalam terjemahan bahasa Indonesia dirumuskan sebagai berikut: "Pihakpihak perjanjian tidak boleh mengemukakan ketentuan-ketentuan hukum nasionalnya sebagai alasan untuk membenarkan tindakan suatu negara tidak melaksanakan perjanjian internasional. Ketentuan ini tidak merugikan pasal 46 Konvensi."

2. Sebagaimana tercantum dalam Undang-Undang Nomor 4 Tahun 2009 tentang Minerba, maka PT. Newmoont Indonesia harus mengubah sistem Kontrak Karya menjadi sistem Izin Usaha Pertambangan Khusus (IUPK). Pada Pasal 103, PT. Newmoont Indonesia juga berkewajiban untuk melakukan pengolahan dan pemurnian hasil penambangan di dalam negeri, selambat-lambatnya lima tahun. 
Selain itu, poin negosiasi yang telah disepakati oleh pemerintah dan PT. Freepoot Indonesia adalah dalam hal wilayah operasi, peningkatan local content, divestasi, dan pembangunan smelter.

Meski menurut Undang-Undang Nomor 4 Tahun 2009, PT. Newmoont Indonesia akan mengalami beberapa perubahan, namun sebagaimana tipe stabilization clauses, pemerintah tetap menjamin kepastian operasional PT. Newmoont Indonesia. Seperti yang sudah dicantumkan pada Pasal 169 Undang-Undang Nomor 4 Tahun 2009, bahwa Kontrak Karya dan perjanjian karya perusahaan pertambangan batubara yang telah ada sebelum berlakunya undang-undang ini tetap diberlakukan sampai jangka waktu berakhirnya kontrak/perjanjian.

Lebih lanjut, dalam Undang-Undang Nomor 3 Tahun 2020 tentang Perubahan Atas Undang-Undang Nomor 4 Tahun 2009 tentang Minerba, asas stabilization clause jelas diterapkan sebagai manifetasi dari sebuah itikad baik perjanjian (karya). Dalam Undang-Undang Nomor 3 Tahun 2020 tersebut telah disisipkan pasal baru sebagai pendukung atau penyempurnaan ketentuan dari Undang-Undang Nomor 4 Tahun 2009, salah satunya yang berkenaan dengan permasalahan PT. Newmoont Indonesia adalah jaminan keberlangsungan operasionalnya.

PT. Newmoont Indonesia diberikan jaminan perpanjangan menjadi IUPK yang sebelumnya Kontrak Karya, setelah memenuhi persyaratan dengan ketentuan: Pertama, kontrak/perjanjian yang belum memperoleh perpanjangan dijamin mendapatkan 2 kali perpanjangan dalam bentuk IUPK sebagai Kelanjutan Operasi Kontrak/Perjanjian masing-masing untuk jangka waktu paling lama 10 tahun sebagai kelanjutan operasi setelah berakhirnya KK atau PKP2B dengan mempertimbangkan upaya peningkatan penerimaan negara. Kedua, Kontrak/perjanjian yang telah memperoleh perpanjangan pertama dijamin untuk diberikan perpanjangan kedua dalam bentuk IUPK sebagai Kelanjutan Operasi Kontrak/Perjanjian untuk jangka waktu paling lama 10 tahun sebagai kelanjutan operasi setelah berakhirnya perpanjangan pertama KK atau PKP2B dengan mempertimbangkan upaya peningkatan penerimaan negara.

Maka sesungguhnya, Kontrak Karya PT. Newmoont Indonesia dan pemerintah telah memakai asas stabilization clause sebagai jaminan atas kepastian investasi usaha yang dilaksanakan oleh PT. Newmoont Indonesia. Meski demikian, mengingat dinamika yang terjadi dari masa ke masa, sebagai negara yan berdaulat, Indonesia berhak melakukan perubahan atas yang telah disepakati dengan PT. Newmoont Indonesia. Perubahan yang dimaksud adalah sebagai implementasi dari tugas negara yang telah diamanahkan oleh Undang-Undang Dasar Negara Republik Indonesia tahun 1945, yaitu menguasai segala sumber daya alam (SDA) agar dimamfaatkan untuk kemakmuran rakyat. Maka jika selama ini Kontrak Karya PT. Newmoont Indonesia justru berbanding terbalik dengan UUD tahun 1945 itu, sehingga membawa ketidaksejahteraan bagi masyarakat Indonesia, pemerintah wajib melakukan perubahan dan menyesuaikan dengan berpegang teguh pada kehendak baik, layak, sekaligus berkeadilan. 


\section{Daftar Pustaka}

\section{Buku}

A. Maley, Geoarge, sebagaimana dikutip dari Arianto Sangaji, Buruk Inco Rakyat Digusur, Pustaka Sinar Harapan, Jakarta, 2002.

Salim HS. H., dan Budi Sustrisno, Hukum Investasi di Indonesia, PT Rajagrafindo Persada, 2008.

Tri Hastuti, Nanik, Hukum Kontrak Karya, Setara Press 2013.

\section{Peraturan Perundang-Undangan}

Undang-Undang Nomor 4 Tahun 2009 tentang Pertambangan Mineral dan Batubara.

Undang-Undang Nomor 3 Tahun 2020 tentang Perubahan Atas Undang-Undang Nomor 4 Tahun 2009 tentang Mineral dan Batubara.

\section{Internet}

Rosa Folia, Memahami Sejarah Panjang Kontrak Newmoont di Indonesia, https://www.idntimes.com/business/economy/rosa-folia/memahami-sejarahpanjang-kontrak-Newmoont-di-indonesia/5.

Hafizh Mulia, Sejarah Newmoont di Indonesia dan Mengapa Keberadaannya Begitu Kontroversial, https://asumsi.co/post/inilah-sejarah-dan-pelanggaranpelanggaran-yang-dilakukan-Newmoont-selama-di-indonesia.

Giri Ahmad Taufik, Peneleti Pusat Studi Kebijakan Hukum, Kompas 11-7-2014.

http:// Newmoont.com. Diakses pada 16 Januari 2017. 